\title{
Harmonisasi Hukum Dalam Perjanjian Sewa Menyewa Barang Milik Daerah Kota Bekasi
}

\author{
Gatot Irfan Wibisono*
}

\begin{abstract}
Abstrak
Pemanfaatan Barang Milik Daerah (BMD) Kota Bekasi adalah pendayagunaan BMD Kota Bekasi yang tidak digunakan untuk penyelenggaraan tugas dan fungsi satuan kerja perangkat daerah dan/atau optimalisasi Barang Milik Daerah dengan tidak mengubah status kepemilikannya. Pemanfaatan BMD Kota Bekasi memberikan peluang bagi daerah untuk meningkatkan pendapatan asli daerah (PAD) Kota Bekasi serta meningkatkan fasilitas publik. Rumusan masalah bagaimana harmonisasi hukum dalam perjanjian sewa menyewa barang milik daerah berrbentuk tanah/bangunan ?Tujuan penelitian yaitu untuk menganalisa harmonisasi hukum dalam perjanjian sewa menyewa barang milik daerah. Kegunaan penelitian ini dapat memberikan wawasan harmonisasi hukum dalam perjanjian sewa menyewa barang milik daerah. Metode penelitian yuridis normatif. Hasil penelitian menunjukan bahwa dalam proses pelaksanaan sewa di Kota Bekasi masih terdapat hambatan yang dilakukan oleh aparatur pemerintah dalam menjalanakan tugas dan fungsinya. Namun dalam proses pelaksanaan pemanfaatan BMD sudah sesuai dengan yang di amanatkan oleh undang-undang yang mengatur terkait pemanfaatana BMD. Kesimpulan yaitu terdapat harmonisasi hukum dimana dijelaskan dari struktur undang-undang samapai pada peraturan daerah
\end{abstract}

Kata Kunci: Harmonisasi Hukum, Perjanjian, Sewa dan Barang Milik Daerah (BMD)

\section{Legal Harmonization in a Lease Agreement Regional Property of Bekasi City}

\begin{abstract}
Utilization of Regional Owned Property (BMD) of Bekasi City is the utilization of Bekasi City BMD that is not used to carry out the duties and functions of regional apparatus work units and / or optimizing Regional Property without changing its ownership status. The use of BMD in Bekasi City provides an opportunity for the region to increase local revenue (PAD) of Bekasi City and improve public facilities. The formulation of the problem of how the harmonization of the law in the lease agreement to lease property belonging to the area in the form of land / building? The purpose of this research is to analyze the harmonization of the law in the lease agreement to lease goods belonging to the region. The usefulness of this research can provide insight into the harmonization of the law in the lease agreements of regional property. Normative juridical research methods. The results showed that in the process of leasing implementation in Bekasi
\end{abstract}

*E-mail : gatot_irfan@gmail.com 
City there were still obstacles that were carried out by the government apparatus in carrying out their duties and functions. But in the process of implementing the use of $B M D$ is in accordance with that mandated by the law governing the use of BMD. The conclusion is that there is a legal harmonization which is explained from the structure of the law until the regional regulations.

Keywords: Law Harmonization, Agreements, Leases and Regional Property (BMD)

\section{Pendahuluan}

Undang-Undang Dasar Negara Republik Indonesia Tahun 1945 Pasal 33 Ayat 3 mengatur bahwa: "Bumi dan air dan kekayaan alam yang terkandung di dalamnya dikuasai oleh Negara dan dipergunakan untuk sebesar-besar kemakmuran rakyat" Fenomena yang terjadi dalam pelaksanaan tugas dan wewenang oleh pemerintah daerah kota Bekasi adalah Pertumbuhan penduduk yang pesat sehingga menyebabkan semakin terbatasnya ketersediaan tanah. Hal ini berpengaruh pada semakin banyaknya permasalahan yang berkaitan dengan tanah.Negara mempunyai peran penting untuk mengatasi masalah yang berkaitan dengan keberadaan tanah tersebut. Dalam mengatasi permasalahan tersebut maka pemerintah daerah memanfaatkan aset berupah tanah/bangunan dalam bentuk perjanjian sewa menyewa dengan tujuan untuk menyelesaikan masalah tanah dalam masyarakat dan meningkatkan pendapatan asli daerah (PAD).Oleh sebab itu barang milik daerah merupakan unsur penting yang harus dikelolah secara tertib, baik, benar, dan mematuhi asas-asas pengelolaanya agar dapat dimanfaatkan secara optimal, efektif, efisien, tidak menimbulkan pemborosan dan dapat dipertanggungjawabkan.

Aset atau barang milik daerah yang merupakan sumber daya ekonomi milik daerah yang mempunyai perang dan fungsi yang strategis bagi pemerintah daerah dalam meningkatkan pelayanan publik kepada masyarakat. Aset yang ditata dan dikelolah dengan baik dapat menjadi potensi sumber pembiayaan pelaksanaan fungsi-fungsi daerah serta dapat pula meningkatkan pendapatan asli daerah (PAD) dalm jumlah yang signitifikan, tetapi jika tidak dikelolah dengan semestinya aset tersebut justru menjadi beban biaya karena sebagian dari aset membutuhkan biaya perawatan atau pemeliharaan dan juga turun nilainya 
(terdepresiasi) seiring dengan perjalanan waktu. Penatausahaan aset daerah harus berdasarkan pada kebijakan dan regulasi yang telah disepakati bersama antara pemerintah pusat dan pemerintah daerah serta pihak-pihak terkait lainnya.

Peraturan perundang-undangan yang menjadi payung hukum pemanfaatan Barang Milik Negara/Daerah (BMN/D) adalah Undang-Undang No. 9 Tahun 2015 Perubahan kedua atas Undang-undang No. 23 Tahun 2014 tentang Pemerintah Daerah, Undang-Undang No. 17 tahun 2003 tentang Keuangan Negara dan Undang-Undang No. 1 tahun 2004 tentang Perbendaharaan Negara. Pengertian dari Barang Milik Negara (BMN) adalah semua barang yang dibeli atau diperoleh atas beban Anggaran Pendapatan dan Belanja Negara (APBN) atau berasal dari perolehan lainnya yang sah.Barang Milik Daerah (BMD) adalah semua barang yang dibeli atau diperoleh atas beban Anggaran Pendapatan dan Belanja Daerah (APBD) atau berasal dari perolehan lainnya yang sah.Peraturan perundang-undangan lain tentang BMN/D yang merupakan turunan dari kedua Undang-Undang tersebut adalah Peraturan Pemerintah (PP) No. 27 Tahun 2014 tentang Pengelolaan Barang Milik Negara/Daerah. PP No. 27 Tahun 2014 tersebut mencabut PP No.06 Tahun 2006 sebagaimana diubah dengan PP No. 38 Tahun 2008 tentang Pengelolaan Barang Milik Negara/Daerah. Sedangkan peraturan pelaksana dari PP No. 06 Tahun 2006 dan PP No. 38 tahun 2008 masih tetap berlaku sepanjang tidak bertentangan dengan PP No. 27 Tahun 2014, dan peraturan yang sudah tidak sesuai dengan peraturan baru tersebut harus disesuaikan paling lama 2 tahun.

Dalam PP No. 27 Tahun 2014, pemanfaatan BMN dan BMD diatur pada Bab VI Pasal 26 sampai dengan Pasal 41. Salah satu bentuk pemanfaatan barang dalam ketentuan dari Bab VI tersebut adalah ketentuan tentang sewa BMN/BMD yang diatur dalam Pasal 28 dan 29. Pengaturan lebih lanjut tentang sewa Peraturan Menteri Dalam Negeri Nomor 19 Tahun 2016 tentang Pedoman Pengelolaan Barang Milik Daerah untuk selanjutnya disebut Permendagri No. 19 Tahun 2016, untuk mengatur secara rinci terkait tatacara pengelolaan barang milik daerah yang merupakan kewenangan pemerintah daerah. 
Adapun ruang lingkup yang diatur pada Pasal 2 Permendagri No. 19 Tahun 2016 ialah: a). Perencanaan kebutuhan dan penganggaran, b). Pengadaan, c). Penerimaan, penyimpanan dan penyaluran, d). Penggunaan, e), Penatausahaan, f). Pemanfaatan, g).Pengamanan dan pemeliharaan h).Penilaian, i).Penghapusan, j).Pemindahtanganan, k).Pembinaan, pengawasan dan pengendalian, k).Pembiayaan, dan 1).Tuntutan ganti rugi.

Berdasarkan ruang lingkup yang disebutkan di atas, dalam Permendagri No. 19 Tahun 2016 terdapat aturan mengenai pemanfaatan, pemanfaatan yang di maksud adalah pendayagunaan barang milik daerah yang tidak digunakan untuk penyelenggaraan tugas dan fungsi Satuan Kerja Perangkat Daerah (SKPD) dan/atau optimalisasi barang milik daerah dengan tidak mengubah status kepemilikan.

Pemanfaatan barang milik daerah dilaksanakan berdasarkan persetujuan Gubernur/Bupati/Walikota, sedangkan untuk barang milik daerah yang berada dalam penguasaan pengelola barang dilaksanakan dengan persetujuan pengelola barang yang di mana barang milik daerah berupa sebagian tanah dan/atau bangunan yang masih digunakan oleh pengguna barang, dan selain tanah dan/atau bangunan.Dalam pelaksanaan pemanfaatan barang milik daerah harus berdasarkan pertimbangan teknis dengan memperhatikan kepentingan daerah dan kepentingan umum dan dapat dilakukan sepanjang tidak mengganggu pelaksanaan tugas dan fungsi penyelenggaraan pemerintahan daerah dengan tanpa memerlukan persetujuan Dewan Perwakilan Rakyat Daerah (DPRD).

Kebijakan pemanfaatan BMD berada di tangan Kepala Daerah, yang harus memenuhi kriteria :

1. Pemanfaatan barang milik daerah berupa tanah dan/atau bangunan, selain tanah dan/atau bangunan yang dipergunakan untuk menunjang penyelenggaraan tugas pokok dan fungsi Satuan Kerja Perangkat Daerah (SKPD), dilaksanakan oleh pengguna setelah mendapat persetujuan pengelola.

2. Pemanfaatan barang milik daerah berupa tanah dan/atau bangunan yang tidak dipergunakan untuk menunjang penyelenggaraan tugas pokok dan 
fungsi SKPD, dilaksanakan oleh pengelola setelah mendapat persetujuan Kepala Daerah.

3. Pemanfaatan barang milik daerah selain tanah dan/atau bangunan yang tidak dipergunakan untuk menunjang penyelenggaraan tugas pokok dan fungsi SKPD, dilaksanakan oleh pengguna setelah mendapat persetujuan pengelola.

4. Pemanfaatan barang milik daerah dilaksanakan berdasarkan pertimbangan teknis dengan memperhatikan kepentingan negara/daerah dan kepentingan umum.

BMD yang menganggur jika tidak didayagunakan tidak akan dapat memberikan manfaat. BMD yang tidak dimanfaatkan atau menganggur untuk menyelenggarakan tugas pokok dan fungsi pemerintah daerah tersebut, dapat didayagunakan dengan jalan disewakan. Pemanfaatan BMD dengan cara disewakan ini akan meningkatkan penerimaan/pendapatan daerah. Selain itu, dengan disewakan BMD dapat mengurangi beban APBD yaitu terkait dengan berkurangnya atau hilangnya biaya pemeliharaan karena ditanggung oleh penyewa.

Sejalan dengan pelaksanaan sewa-menyewa tanah/bangunan milik daerah sebagaimana diatur dalam Permendagri No.19 Tahun 2016 diatas, lebih mengacuh pada Undang-Undang No. 9 Tahun 2015 jo Undang-undang No. 23 Tahun 2014 tentang Pemerintah Daerah dan tidak mengacuh pada UndangUndang No. 5 Tahun 1960 tentang Peraturan Dasar Pokok-Pokok Agraria (selanjutnya disebut UUPA). Artinya bahwa Permendagri lahir dari kebijakan Undang-Undang No. 9 Tahun 2015 jo Undang-undang No. 23 Tahun 2014 tentang Pemerintah Daerah dan bukan dari UUPA

Penjelasan terkait sewa menyewah dalam UUPA sendiri di atur dalam Pasal 44 UUPA yang menyatakan: (1) Seseorang atau suatu badan hukum mempunyai hak sewa atas tanah, apabila ia hendak mempergunakan tanah milik orang lain untuk keperluan bangunan, dengan membayar kepada pemiliknya sejumlah uang sewa. (2) Pembayaran uang sewa dapat di-lakukan: a. Satu kali atau pada tiaptiap bulan tertentu; b. Sebelum atau sesudah tanah dipergunakan. (3) Perjanjian 
sewa tanah yang dimaksud dalam pasal ini tidak boleh disertai syarat-syarat yang mengandung unsur pemerasan.

Subyek dari hak sewa tersebut dapat kita temukan pada Pasal 45 UUPA yaitu : 1. Warga negara Indonesia; 2. Orang asing yang berkedudukan di Indonesia; 3. Badan-badan hukum yang didirikan menurut hukum Indonesia dan berkedudukan di Indonesia; 4. Badan hukum asing yang mempunyai perwakilan di Indonesia.

Jadi hal ini menunjukan ketidak harmonisasian antara Undang-Undang No. 9 Tahun 2015 jo Undang-undang No. 23 Tahun 2014 tentang Pemerintah Daerah dan UUPA. Hal ini tentu saja sangat bertentangan dengan asas "Lex Superior Derogat Lex Inferiors", artinya ketentuan hukum yang lebih tinggi akan mengalahkan ketentuan hukum yang ada di bawahnya. Dengan kata lain ketentuan hukum yang ada dibawah tidak boleh bertentangan dengan ketentuan hukum yang di atasnya, yaitu Permendagri No. 19 Tahun 2016 tentang Pedoman Pengelolaan Barang Milik Daerah tidak boleh bertentangan dengan UUPA Tahun 1960 .

Jadi Permendagri No. 19 Tahun Tahun 2016 ini harus mengacu pada dua perundang-undangan yang berlaku baik dari UUPA maupun Undang-Undang No. 9 Tahun 2015 jo Undang-undang No. 23 Tahun 2014 tentang Pemerintah Daerah dan UUPA sehingga akan menimbulkan harmonisasi dalam pembentukanya. Berdasarkan latar belakang di atas, maka rumusan masalah dalam penelitian ini yaitu bagaimana harmonisasi hukum sewa menyewa Barang Milik Daerah berdasarkan perundangan?

\section{Pembahasan}

\section{A. Harmonisasi Hukum dalam Perjanjian Sewa Tanah/Bangunan}

\section{Pengertian Harmonisasi Hukum}

Kata harmonisasi ini, di dalam bahasa inggris disebut harmonize, dalam bahasa Francis disebut dengan harmonie, dan dalam bahasa yunani disebut harmonia.(Suhartono:2011:94) Dan istilah harmonisasi hukum itu sendiri muncul dalam kajian ilmu hukum pada tahun 1992 di Jerman.Dimana 
kajian harmonisasi hukum ini dikembangkan dengan tujuan untuk menunjukkan bahwa dalam dunia hukum, kebijakan pemerintah, dan hubungan diantara keduannya terdapat keaneragaman yang dapat mengakibatkan disharmoni.

Adapun cakupan harmonisasi hukum, L.M Gandhi yang mengutip buku tussen eenheid en verscheidenheid: Opstellen over harmonisatie instaaat en bestuurecht (1988) mengatakan bahwa harmonisasi dalam hukum adalah mencakup penyesuaian peraturan perundang-undangan, keputusan pemerintah, keputusan hakim, sistem hukum dan asas-asas hukum dengan tujuan peningkatan kesatuan hukum, kepastian hukum, keadilan (justice,gerechtigheid) dan kesebandingan (equit, billijkeid), kegunaan dan kejelasan hukum, tanpa mengaburkan dan mengorbankan pluralisme hukum kalau memang dibutuhkan. Sementara menurut Badan Pembinaan Hukum Nasional dalam buku yang disusun oleh Moh. Hasan Wargakusumah dan kawan-kawan, harmonisasi hukum adalah kegiatan ilmiah untuk menuju proses pengharmonisasian tertulis yang mengacu baik pada nilai-nilai filosofis, sosiologis, ekonomis maupun yuridis.(Suhartono:2011:95)

Dari uraian diatas dapat disimpulkan bahwa harmonisasi hukum diartikan sebagai upaya atau proses penyesuaian asas dan sistem hukum, agar terwujud kesederhanaan hukum, kepastian hukum dan keadilan. Harmonisasi hukum sebagai suatu proses dalam pembentukan peraturan perundang-undangan, mengatasi hal-hal yang bertentangan dan kejanggalan di antara norma-norma hukum di dalam peraturan perundang-undangan, sehingga terbentuk peraturan perundang-undangan nasional yang harmonis, dalam arti selaras, serasi, seimbang, terintegrasi dan konsisten, serta taat asas.

\section{Ruang Lingkup Harmonisasi Hukum}

Penerapan peraturan perundang-undangan dalam jumlah banyak secara bersamaan dalam waktu dan ruang yang sama, sudah tentu membawa konsekuensi terjadinya disharmoni hukum. Misalnya terjadinya tumpang tindih kewenangan dan benturan kepentinngan. Penerapan berbagai macam 
peraturan perundang-undangan secara bersama-sama tanpa upaya-upaya harmonisasi hukum atau penyelelarasan dan penyerasian sudah tentu akanmenimbulkan benturan kepentingan antar lembaga. Masing-masing peraturan perundang-undangan memiliki tujuan, strategi untuk mencapai tujuan, dan pedoman untuk melaksanakan strategi, dimana ketiganya ini sering dirumuskan dalam bentuk kebijakan-kebijakan.

Kebijakan terdiri dari dua macam, yaitu kebijakan yang bersifat tetap atau regulatory policies yang diterapkan dalam berbagai bentuk peraturan pelaksanaan dari peraturan yang lebih tinggi tingkatannya dan kebijakan yang bersifat tidak tetap, yaitu yang mudah diubah dalam rangka mengikuti perkembangan. Dalam kaitannya ini, harmonisasi hukum dapat diawali dengan melakukan penyelarasan dan penyerasian tujuan, strategi, dan pedoman dari masing-masing peraturan perundangundangan melalui upaya penafsiran hukum, konstruksi hukum, penalaran hukum, dan pemberian argumentasi yang rasional dengan tetap memperhatikan sistem hukum dan asas hukum yang berlaku.

Harmonisasi hukum dalam sisi pencegahan, yaitu upaya harmonisasi yang dilakukan dalam rangka menghindarkan terjadinya disharmoni hukum.Dishrmoni hukum yang telah terjadi memerlukan harmonisasi sistem hukum untuk mewujudkan tata pemerintahan yang baik, dan disharmonisasi hukum yang belum terjadi harus dicegah melalui upayaupaya penyelarasan, penyerasian, dan penyesuwaian berbagai kegiatan harmonisasi hukum.Demikian pula halnya, inkonsistensi dalam penjatuhan sangsi terhadap pelanggaran hukum menimbulkan terjadinya disharmoni hukum yang harus diharmonisasikan melalui kegiatan penyerasian dan penyelarasan hukum.

Disamping itu, harmonisasi hukum dilakukan untuk menanggulangi keadaan disharmoni hukum yang telah terjadi.Keadaan disharmoni hukum yang terlihat dalam realita, misalnya, tumpang tindih kewenangan, persaingan tidak sehat, sengketa, pelanggaran, benturan kepentingan, sengketa, pelanggaran, persaingan tidak sehat, dan tindak pidana.Sehingga 
dalam rangka menanggulangi disharmoni antara kepentingan yang menyangkut masalah di atas, harus ada upaya harmonisasi.Misalnya dalam upaya kasus perdata bisa melalui Alternative Dispute Resolution (ADR).

Dan potensi terjadinya disharmonisasi hukum menurut Kusnu Goesniadhie tercermin oleh adanya factor-faktor sebagai berikut (Kusnu Goesniadhie:2010:11).

a. Jumlah peraturan perundang-undangan terlalu banyak yang diberlakukan

b. Perbedaan kepentingan dan penafsiran

c. Kesenjangan antara pemahaman teknis dan pemahaman hukum tentang tata pemerintahan yang baik.

d. Kendala hukum yang dihadapai dalam penerapan peraturan perundangundangan, yang terdiri dari mekanisme pengaturan, administrasi pengaturan, antisipasi terhadap perubahan, dan penegakan hukum.

e. Hambatan hukum yang dihadapi dalam penerapan peraturan perundangundangan, yaitu yang berupa tumpang tindih kewenangan dan benturan kepentingan.

\section{Fungsi Harmonisasi Hukum}

Harmonisasi hukum mempunyai fungsi pencegahan dan fungsi penaggulangan terjadinya disharmoni hukum.Harmonisasi hukum untuk mencegah terjadinya disharmonisasi hukum, dan hal ini dilakukan melalui penemuan hukum (penafsiran dan konstruksi hukum), penalaran hukum, dan pemberian argumentasi yang rasional.Upaya ini dilakukan dengan arahan untuk menegaskan kehendak hukum, kehendak masyarakat, dan kehendak moral.Harmonisasi hukum yang bersifat pencegahan dilakukan dalam rangka mengantisipasi kenyataan tentang adanya factor-faktor potensial yang dapat menyebabkan terjadinya disharmonisasi hukum.

Harmonisasi hukum untuk menaggulangi terjadinya disharmonisasi hukum, dilakukan melalui: (Kusnu Goesniadhie:2010:12). 
a. Proses non-litigasi melalui alternative dispute resolution (ADR) untuk menyelesaikan persoalan sengketa perdata di luar pengadilan.

b. Proses litigasi melalui court-connected dispute resolution (CCDR) untuk mendamaikan para pihak yang bersangkutan di bidang perdata sebelum dimulai pemeriksaan di pengadilan.

c. Proses litigasi sebagai pemeriksaan perkara perdata di pengadilan.

d. Proses negosiasi atau musyawarah, baik dengan mediator atau tidak untuk menyelesaikan disharmoni hukum publik yang tidak bersifat pidana, seperti tumpang-tindih kewenangan dan benturan kepentingan antar instansi pemerintah.

e. Proses pemeriksaan perkara pidana untuk mengadili pelanggaran atau tindakan kejahatan.

Sementara itu Wacipto Setiadi berpenapat bahwa selain untuk memenuhi ketentuan pasal 18 ayat (2) Undang-Undang No. 10 Tahun 2004 tentang Pembentukan Peraturan Perundang-Undangan, paling tidak ada tiga alasan atau fungsi harmonisasi hukum, yaitu:

a. Pengharmonisasian dilakukan untuk menjaga keselarasan, kemantapan, dan kebulatan konsepsi peraturan perundang-undangan sebagai sistem dengan tujuan peraturan tersebut dapat berfungsi secara efektif.

b. Harmonisasi hukum dilakukan sebagai upaya prefentif, dalam rangka pencegahan diajukannya permohonan judicial review peraturan perundangundangan kepada kekuasaan kehakiman yang berkompeten.

c. Menjamin proses pembentukan peraturan perundang-undangan dilakukan secara taat asas hukum, demi kepentingan dan kepastian hukum (Wacipto Setiadi: 2007:48).

Melihat pendapat diatas, dapat disimpulkan bahwa harmonisasi hukum berfungsi untuk mencegah dan menanggulangi disharmoni hukum.Hal ini selaras dengan definisi dan ruang lingkup harmonisasi yang telah disebutkan diatas, bahwa harmonisasi hukum dapat digunakan untuk 
pengharmonisasian peraturan perundangundangan dan juga untuk peraturan perundang-undangan yang sudah ada sebelumnya (penanggulangan).

\section{Langkah-Langkah Harmonisasi Hukum}

Sehubungan dengan langkah-langkah harmonisasi hukum, Kusnu Goesniadhie membaginya menjai lima langkah yaitu:

a. Identifikasi letak disharmoni hukum dalam penerapan peraturan perundangundangan;

b. Identifikasi letak disharmoni hukum dalam penerapan peraturan perundangundangan;

c. Upaya penemuan hukum dengan menggunakan metode penafsiran dan metode konstruksi hukum untuk mengubah keadaan hukum yang disharmoni menjadi harmoni;

d. Upaya penalaran hukum agar hasil penafsiran dan konstruksi hukum tersebut masuk akal atau memenuhi unsur logika;

e. Penyusunan argumentasi yang rasional dengan mempergunakan pemahaman tata pemerintahan yang baik untuk mendukung dan menjelaskan hasil penafsiran hukum, konstruksi hukum, dan penalaran hukum.(Kusnu Goesniadhie:2010:13)

\section{Pendekatan Harmonisasi Hukum}

Pendekatan harmonisasi hukum, Goesniadhie dalam bukunya yang berjudul "Harmonisasi Sistem Hukum: Mewujudkan Tata Pemerintahan yang Baik" ia menyebutkan ada 4 macam dalam pendekatan harmonisasi hukum, yaitu : (Kusnu Goesniadhie:2010:17).

a. Harmonisasi hukum mengacu pada perundang-undangan

Harmonisasi peraturan perundang-undangan dapat diartikan sebagai suatu proses penyelarasan atau penyerasian peraturan perundangundangan yang hendak atau sedang disusun, sehingga peraturan perundang-undangan yang dihasilkan sesuai dengan prinsip-prinsip hukum dan peraturan perundangundangan yang baik. Dalam hal ini, 
harmonisasi hukum memegang peranan yang sangat strategis dan harus dimulai sejak tahap perencanaan agar memudahkan proses selanjutnya.

Harmonisasi hukum tidak hanya menyangkut hal-hal yang bersifat yang dimaksudkan untuk menghindari pengaturan yang tumpang tindih atau saling bertentangan seperti yang diuraikan diatas.Harmonisasi hukum juga mempunyai peranan penting dalam melahirkan suatu produk peraturan perundang-undangan yang dapat dijalankan dan diterima oleh masyarakat dengan baik.

Harmonisasi peraturan perundang-undangan, tidak hanya terbatas pada macam atau jenis peraturan perundang-undangan beserta tata urutannya. Secara ideal dilakukan terintegrasi yang meliputi segala aspek dari paham peraturan perundang-undangan, yaitu: a) pengertian umum peraturan perundang-undangan; b) makna urutan peraturan perundangundangan; c) fungsi tata urutan peraturan perundang-undangan; d) penamaan masingmasing peraturan perundang-undangan; e) pengertian masing-masing peraturan perundang-undangan; f) hubungan norma peraturan perundangundangan dengan norma hukum yang lain.

Harmonisasi peraturan perundang-undangan merupakan upaya penyelarasan dan penyerasian tujuan, strategi, dan pedoman dilaukan dengan mengacu pada hukum dasar yaitu UUD 1945 dan peraturan perundangundangan yang mendasari tata pemerintahan yang baik. Disamping itu, harus selaras dan serasi dengan perubahan hukum dasar dan hukum yang mendasarinya menuju tata pemerintahan yang baik.

b. Harmonisasi hukum mengacu ruang lingkup

Adalah harmonisasi hukum dalam pengertian upaya harmonisasi tujuan, strategi untuk mencapai tujuan, dan pedoman untuk melaksanakan strategi agar tujuan dari masing-masing peraturan perundang-undangan tercapai

c. Harmonisasi hukum mengacu pada keterpaduan kelembagaan.

Aspek hukum atau kelembagaan dalam tata pemerintahan yang baik diwujudkan dalam bentuk intraksi hukum dan kelembagaan.Oleh karena 
intraksi hukum dan kelembagaan terjadi di setiap komponen kegiatan dan juga antara kompenen kegiatan, maka keterpaduan tersebut hendaknya diupayakan untuk terwujud disetiap tingkatan intraksi hukum dan kelembagaan.

Upaya untuk memadukan peraturan perundang-undangan, menyelaraskan, dan menyerasikan dapat dilakukan melalui penafsiran hukum, penalaran hukum, dan argumentasi rasional dengan memperhatikan kepentingan masing-masing lembaga dengan arahan utama untuk mengembangkan suatu produk hukum yang baik.Apabila keterpaduan hukum dapat terwujud, maka keterpaduan dalam apliksinya juga harus selalu selaras dangan nila-nilai muatan agama. Sehingga keterpaduan kelembagaan senantiasa akan menjadi jaminan bagi diselenggarakannya harmonisasi hukum dalam mewujudkan produk hukum yang baik.

d. Harmonisasi hukum mengacu pada kodifikasi dan unifikasi

Upaya kodifikasi dan unifikasi hukum merupakan upaya untuk membatasi dan mengunci hasil harmonisasi hukum agar tidak berubah lagi.Jika terjadi perubahan, maka perubahan tersebut harus mengacu pada unifikasi hukum yang telah dikodifikasikan.Upaya kodifikasi adalah upaya untuk menghimpun peraturan perundang-undangan ke dalam satu buku. Unifikasi hukum ditandai dengan karakteristik sebagai berikut: 1) adanya satu kitab undang-undang; 2) adanya satu persepsi atau satu pemahaman tentang hukum yang berlaku; 3) adanya satu sikap dan prilaku terhadap hukum yang berlaku; 4) adanya prinsip-prinsip nondiskriminatif; 5) adanya konsistensi dalam penerapan dan penegakan hukum.

Terwujudkan kodifikasi dan unifikasi hukum akan menjamin terwujudnya kepastian hukum dan keadilan. Disamping itu, kodifikasi dan unifikasi hukum akan menjadi landasan bagi pengembangan dinamika harmonisasi hukum. 


\section{B. Harmonisasi Hukum Pemanfaatan Barang Milik Daerah}

Tabel Harmonisasi Hukum Pemanfaatan Barang Milik Daerah

\begin{tabular}{|c|c|c|c|c|}
\hline Peraturan & $\begin{array}{c}\text { Pemanfaatan Barang Milik } \\
\text { Daerah }\end{array}$ & Pasal & Objek & Subjek \\
\hline \multirow[t]{2}{*}{$\begin{array}{c}\text { Undang- } \\
\text { Undang No. } 5 \\
\text { Tahun } 1960 \\
\text { tentang Dasar } \\
\text { Pokok Agraria }\end{array}$} & $\begin{array}{l}\text { (1) Segala usaha bersama dalam } \\
\text { lapangan agraria didasarkan } \\
\text { atas kepentingan bersama dalam } \\
\text { rangka kepentingan nasional, } \\
\text { dalam bentuk koperasi atau } \\
\text { bentuk-bentuk gotong royong } \\
\text { lainnya. } \\
\text { (2) Negara dapat bersama-sama } \\
\text { dengan pihak lain } \\
\text { menyelenggarakan usaha-usaha } \\
\text { dalam lapangan agraria. }\end{array}$ & $\begin{array}{l}\text { Pasal } 12 \\
\text { Ayat (1) } \\
\text { dan (2) }\end{array}$ & $\begin{array}{l}\text { Tanah dan } \\
\text { Bangunan }\end{array}$ & $\begin{array}{l}\text { Pemerintah } \\
\text { pusat atau } \\
\text { pemerintah } \\
\text { daerah dan } \\
\text { Badan Hukum } \\
\text { atau } \\
\text { Peroranagan }\end{array}$ \\
\hline & $\begin{array}{l}\text { (1) Seseorang atau suatu badan } \\
\text { hukum mempunyai hak sewa } \\
\text { atas tanah, apabila ia berhak } \\
\text { mempergunakan tanah milik } \\
\text { orang lain untuk keperluan } \\
\text { bangunan, dengan membayar } \\
\text { kepada pemiliknya sejumlah } \\
\text { uang sebagai sewa. }\end{array}$ & $\begin{array}{l}\text { Pasal } 44 \\
\text { Ayat } 1\end{array}$ & Tanah & $\begin{array}{c}\text { Pemerintah } \\
\text { pusat atau } \\
\text { pemerintah } \\
\text { daerah dan } \\
\text { Badan Hukum } \\
\text { atau } \\
\text { Peroranagan }\end{array}$ \\
\hline $\begin{array}{c}\text { Undang- } \\
\text { Undang No. } \\
23 \text { Tahun } \\
2014 \text { tentang } \\
\text { Pemerintah } \\
\text { Daerah }\end{array}$ & $\begin{array}{l}\text { Hasil pengelolaan kekayaan } \\
\text { Daerah yang dipisahkan } \\
\text { sebagaimana dimaksud dalam } \\
\text { Pasal } 285 \text { ayat (1) huruf a } \\
\text { angka } 3 \text { dan lain-lain } \\
\text { pendapatan asli daerah yang sah } \\
\text { sebagaimana dimaksud dalam } \\
\text { Pasal } 285 \text { ayat (1) huruf a angka } \\
4 \text { ditetapkan dengan Perda } \\
\text { dengan berpedoman pada } \\
\text { ketentuan peraturan perundang- } \\
\text { undangan }\end{array}$ & $\begin{array}{l}\text { Pasal } 286 \\
\text { Ayat (3) }\end{array}$ & $\begin{array}{c}\text { Barang } \\
\text { Milik } \\
\text { Negara atau } \\
\text { Daerah }\end{array}$ & $\begin{array}{l}\text { Pemerintah } \\
\text { pusat atau } \\
\text { pemerintah } \\
\text { daerah dan } \\
\text { Badan Hukum } \\
\text { atau } \\
\text { Peroranagan }\end{array}$ \\
\hline $\begin{array}{l}\text { Undang- } \\
\text { Undang No. } \\
17 \text { Tahun } \\
2003 \text { tentang } \\
\text { Keuangan } \\
\text { Negara }\end{array}$ & $\begin{array}{l}\text { Keuangan Negara dikelola } \\
\text { secara tertib, taat pada peraturan } \\
\text { perundang-undangan, efisien, } \\
\text { ekonomis, efektif, transparan, } \\
\text { dan bertanggung jawab dengan } \\
\text { memperhatikan rasa keadilan } \\
\text { dan kepatutan. }\end{array}$ & $\begin{array}{l}\text { Pasal } 3 \\
\text { Ayat (1) }\end{array}$ & $\begin{array}{c}\text { Barang } \\
\text { Milik } \\
\text { Negara atau } \\
\text { Daerah }\end{array}$ & $\begin{array}{c}\text { Pemerintah } \\
\text { pusat atau } \\
\text { pemerintah } \\
\text { daerah dan } \\
\text { Badan Hukum } \\
\text { atau } \\
\text { Peroranagan }\end{array}$ \\
\hline $\begin{array}{c}\text { Peraturan } \\
\text { Pemerintah } \\
\text { No. } 27 \text { Tahun } \\
2014 \text { tentang } \\
\text { Pengelolaan } \\
\text { Barang Milik } \\
\text { Negara/ } \\
\text { Daerah }\end{array}$ & $\begin{array}{l}\text { (1) Sewa Barang } \text { Milik } \\
\text { Negara/Daerah dilaksanakan } \\
\text { terhadap: a. Barang Milik } \\
\text { Negara yang berada pada } \\
\text { Pengelola Barang; b. Barang } \\
\text { Milik Daerah berupa tanah } \\
\text { dan/atau bangunan yang sudah } \\
\text { diserahkan oleh Pengguna } \\
\text { Barang } \\
\text { Gubernur/Bupati/Walikota; c. } \\
\text { Barang Milik Negara yang } \\
\text { berada pada Pengguna Barang; } \\
\text { d. Barang Milik Daerah berupa } \\
\text { sebagian tanah dan/atau } \\
\text { bangunan yang masih } \\
\text { digunakan oleh Pengguna }\end{array}$ & $\begin{array}{c}\text { Pasal } 28 \\
\text { Ayat } 1\end{array}$ & $\begin{array}{l}\text { Tanah atau } \\
\text { Bangunan }\end{array}$ & $\begin{array}{l}\text { Pemerintah } \\
\text { pusat atau } \\
\text { pemerintah } \\
\text { daerah dan } \\
\text { Badan Hukum } \\
\text { atau } \\
\text { Peroranagan }\end{array}$ \\
\hline
\end{tabular}




\begin{tabular}{|c|c|c|c|c|}
\hline & $\begin{array}{l}\text { Barang; atau e. Barang Milik } \\
\text { Daerah selain tanah dan/atau } \\
\text { bangunan. }\end{array}$ & & & \\
\hline $\begin{array}{c}\text { Peraturan } \\
\text { Menteri } \\
\text { Dalam Negeri } \\
\text { No. 19 Tahun } \\
2016 \text { tentang } \\
\text { Pedoman } \\
\text { Pengelolaan } \\
\text { Barang Milik } \\
\text { Daerah }\end{array}$ & $\begin{array}{l}\text { (2) Pemanfaatan barang milik } \\
\text { daerah dilaksanakan } \\
\text { berdasarkan pertimbangan } \\
\text { teknis dengan memperhatikan } \\
\text { kepentingan daerah dan } \\
\text { kepentingan umum. } \\
\text { (3) Pemanfaatan barang milik } \\
\text { daerah dapat dilakukan } \\
\text { sepanjang tidak mengganggu } \\
\text { pelaksanaan tugas dan fungsi } \\
\text { penyelenggaraan pemerintahan } \\
\text { daerah. }\end{array}$ & Pasal 78 & $\begin{array}{l}\text { Tanah dan } \\
\text { Bangunan }\end{array}$ & $\begin{array}{c}\text { Pemerintah } \\
\text { Daerah dan } \\
\text { Badan Usaha } \\
\text { atau Perorangan }\end{array}$ \\
\hline $\begin{array}{c}\text { Peraturan } \\
\text { Daerah Kota } \\
\text { Bekasi No. 04 } \\
\text { Tahun 2009 } \\
\text { tentang } \\
\text { Pengelolaan } \\
\text { Barang Milik } \\
\text { Daerah }\end{array}$ & $\begin{array}{l}\text { (1) Pemanfaatan barang milik } \\
\text { daerah berupa tanah dan/atau } \\
\text { bangunan sebagaimana } \\
\text { dimaksud dalam Pasal 15 ayat } \\
\text { (1) dilaksanakan oleh pengelola } \\
\text { barang setelah mendapat } \\
\text { persetujuan Walikota. } \\
\text { (2) Pemanfaatan barang milik } \\
\text { daerah berupa tanah dan/atau } \\
\text { bangunan yang diperlukan } \\
\text { untuk menunjang } \\
\text { penyelenggaraan tugas pokok } \\
\text { dan fungsi pengguna } \\
\text { barang/kuasa pengguna barang } \\
\text { dilakukan oleh pengguna } \\
\text { barang dengan persetujuan } \\
\text { pengelola barang. } \\
\text { (3) Pemanfaatan barang milik } \\
\text { daerah selain tanah dan/atau } \\
\text { bangunan dilaksanakan oleh } \\
\text { pengguna barang dengan } \\
\text { persetujuan pengelola barang. } \\
\text { (4) Pemanfaatan barang milik } \\
\text { daerah dilaksanakan } \\
\text { berdasarkan pertimbangan } \\
\text { teknis dengan memperhatikan } \\
\text { kepentingan negara dan } \\
\text { kepentingan umum. }\end{array}$ & Pasal 18 & $\begin{array}{l}\text { Tanah dan } \\
\text { Bangunan }\end{array}$ & $\begin{array}{c}\text { Pemerintah } \\
\text { Kota Bekasi } \\
\text { dengan Badan } \\
\text { Usaha atau } \\
\text { Perorangan }\end{array}$ \\
\hline
\end{tabular}

Berdasarkan tabel di atas dapat dilihat harmonisasi hukum di tiap-tiap undang-undang yang dijelaskan di tiap Pasal terkai pemanfaat barang milik negaramaupun pemenafaatn barang milik daerah disertai dengan peraturan tentang pedoman teknis dalam pelaksanaan pengelolaan barang milik daerah yang berupa tanah/bangunan dalam bentuk pemanfaatan dalam sewa dengan disertai prinsip dan tujuan untuk pendapatan asli daerah demi untuk kemajuan, kelancaran dan pendukung dalam menjalankan tugas dan fungsi 
yang di amanatkan oleh undang-undang baik di tingkat pusat maupu tingkat daerah (Kota Bekasi).

\section{Penutup}

\section{A. Kesimpulan}

1. Pelaksanaan pengelolaan barang milik daerah kota Bekasi dalam bentuk pemananfaatan dalam sewa antara pihak pemerintah Kota Bekasi dengan Badan Usaha Milik Negara (BUMN)/Badan Usaha Milik Daerah (BUMD)/Badan Usaha Milik Swasta/Perorangan dilaksanakan berdasarkan ketentuan undang-undang yang berlaku yang mengatur tentang pengelolaan barang milik Negara/daerah yang disertai dengan tujuan dan prinsip pelaksanaan perjanjian sewa dan implikasi dari pelaksanaan sewa barang milik daerah kota Bekasi kepada pemerintahan kota Bekasi yaitu Menambah pemasukan Kas daerah/kota Bekasi, pendapatan yang berbentuk uang sehingga dapat digunakan untuk kegiatan belanja daerah secara berkelanjutan (sustainable) melalui APBD, mengoptimalakan biaya pemeliharaan barang yang berbentuk tanah/bangunan sehingga tidak membebankan APBD kota Bekasi dan Dapat membuka lapangan kerja apabila jenis usaha yang di bangun oleh pihak penyewa membutuhkan kariyawan. Meskipun dalam pelaksanaan sewa barang milik daerah masi terdapat hambatan yang timbul dari kalangan aparatur pemerintah itu sendiri yang mana masi terdapat, Rendahnya kepatuhan aparatur daerah, Inventarisasi aset yang belum efektif dan optimal, kompetensi sumber daya manusia yang belum mendukung pengelolaan aset daerah Kendala pada sumber daya dalam bentuk anggaran dan fasilitas pengelolaan aset daerah. Adapun harmonisasi hukum di tiap-tiap undang-undang yang dijelaskan di tiap Pasal terkai pemanfaat barang milik negaramaupun pemenafaatn barang milik daerah disertai dengan peraturan tentang pedoman teknis dalam pelaksanaan pengelolaan barang milik daerah yang berupa tanah/bangunan dalam bentuk pemanfaatan dalam sewa 
dengan disertai prinsip dan tujuan untuk pendapatan asli daerah demi untuk kemajuan, kelancaran dan pendukung dalam menjalankan tugas dan fungsi yang di amanatkan oleh undang-undang baik di tingkat pusat maupu tingkat daerah sudah terdapat harmonisasi hukum dimana dijelaskan dari struktur undang-undang samapai pada peraturan daerah.

\section{B. Saran}

1. Pelaksanaan pemanfaatan barang milik daerah Kota Bekasi harus lebih ditingkatkan lagi agar semua barang milik daerah yang bisa dimanfaatkan oleh pihak lain dan baran tersebut yang belum atau tidak dimanfaatkan oleh daerah sehingga bisa mengopitamlisasi biaya pemeliharaan barang milik daerah kota Bekasi yang menggunakan APBD dan bisa membuka peluang usaha dan lowongan kerja Kepada Masayarakat khusunya Masyarakat Bekasi

2. Adanya tindakan yang tegas dan pemberian sanksi kepada para aparatur yang tidak menaati peraturan tata tertib pemerintahan kota bekasi dan aparatur pemerintahan kota bekasi yang bekerja di bagian pemanfaatan barang milik daerah harus mempunyai ilmu pengetahuan yang berdasarkan dengan kemampuan dan tingkat pendidikan yang disertai dengan sertifikat pembelajaran dalam pengelolaan maupun perencanaan pemanfaatan barang milik daaerah

\section{Daftar Pustaka}

Kusnu, Goesniadhie, Harmonisasi Sistem Hukum: Mewujukan Tata Pemerintahan Yang Baik, Malang: Nasa Media, 2010.

Attamimi, Hamid A. UUD1945-TAP MPR Undang-Undang (kaitan norma hukum

Wirjono, Prodjodikoro. Hukum Perdata Tentang Persetujuan-persetujuan Tertentu, Bandung : Sumur, 1981.

Indrati, Parida Maria. Ilmu Perundang-undangan, Disarikan dari Perkuliahan Hamid S.Attamimi, Yogyakarta: Kanisius, 1998. 
Purwahid, Patrik. Dasar-Dasar Hukum Perikatan (Perikatan Yang Lahir Dari Perjanjian dan Dari Undang-Undang), Bandung : Mandar Maju, 1994. Hasanuddin, Rahman. Drafting Seri Ketrampilan Merancang Kontrak Bisnis, Bandung: PT. Citra Aditya Bakti, 2003.

Undang-Undang Dasar Negara Republik Indonesia 1995.

Undang-Undang No. 5 Tahun 1960 tentang Peraturan Dasar Pokook Agraria

Undang-Undang No. 12 Tahun 2011 Tentang Pembentukan Peraturan Perundang-Undangan

Undang-Undang No. 23 Tahun 2014 tentang Pemerintah Daerah

Undang-Undang No. 17 Tahun 2003 tentang Keuangan Negara

Undang-Undang No. 1 Tahun 2004 tentang Perbendaharaan Negara 